\title{
Héctor Rubinstein: a compass in science and life
}

\section{Ariel Goobar}

Oskar Klein Centre

Department of Physics

Stockholm University

S-106 91 Stockholm, Sweden

E-mail:ariel@fysik.su.se

Quarks, Strings and the Cosmos - Héctor Rubinstein Memorial Symposium, AlbaNova, Stockholm, Sweden

August 9-11, 2010 
"It's a scandal!" would be the typical opening line of Héctor as we met up for coffee almost every morning at Albanova. Indeed, very few things were up to his high standards, whether the subject was physics, politics, Swedish health care (especially during his last years) or yet another one of our common passions: soccer. Most of the times, I had not even had the slightest thought about the current "scandal” prior to our conversation, but would find myself sharing Héctor's anger within minutes, much to my own surprise! His power of argumentation was extremely vehement and powerful, and I rarely left any of our daily discussions unaffected.

The first time we met was no different. I was finishing my undergraduate studies in Stockholm and had a vague idea that I wanted to try out a career as graduate student, but knew too little about modern physic to know what research field I could undertake. My parents (later among Héctor's and Helen's best friends) suggested I should consult an Argentine physicist they had met a year or so earlier at the embassy of our country of birth. The occasion at that time had been a dinner-party where the guest of honour was César Milstein, the 1984 Argentinian Nobel laureate in physiology, and one of Héctor's many illustrious acquaintances.

Unlike other professors in the corridor, Héctor's door on the 8:th floor of the old physics building at Vanadisvägen was open, and he immediately dropped the papers he had in front of him to listen to what I had to say. I recall that within minutes he had discouraged me to consider theoretical physics, partly because he did not think there was any interesting theory group in the house at that time, but probably mostly due to his shock when he found out how shallow mine and my fellow Swedish student's physics education was. Once theory was declared a non-starter, he went on to tell me that I should stay away from experimental particle physics. I was told it was all "big science politics" and the practitioners were either "operators" or "crooks", whenever they were not a bit of both! I was totally convinced that I was not going to get into that field, for sure. Within the next half hour, Héctor and I had gone through the list of professors in the other experimental areas...needless to say, Héctor was not impressed. At that point Hector was convinced that experimental particle physics, with the start of the LEP accelerator within the horizon was just right for me... and had fully convinced me!

I went on to become a graduate student in Gösta Ekspong's group working on the DELPHI detector and was fortunate enough to be stationed at CERN for 2 years during the LEP start-up and work on the search for the Standard Model Higgs boson.

From day one Héctor followed my progress there with great interest and, as with everyone else he knew, he would often interrogate me to find out if there was any sign of a discovery at CERN- of any kind. Héctor took a special pride in being informed of the latest news. On the occasions he visited CERN, he would summon me and Jorge (Giora) Mikenberg, a Weizmann Argie, and senior scientist in the competing OPAL experiment. While we were having fascinating discussions, from which I learned a lot about state of the art physics, Héctor was getting out of us exactly how many events there were of each kind and what room there was for new physics in our data... in return he would inform us about the latest "scandals" in Sweden (Giora used to tell me 
that the "scandals" were not fewer in Israel when Héctor lived there), and would crack some fantastic jokes that would leave me laughing for days.

Around the time I was finishing my thesis, Héctor made the transition to Astroparticle physics, sweeping everyone around him in the process, myself included. With his decisive support, in 1992 I landed at a post-doc in Berkeley to work on supernova cosmology, at the time a totally obscure field. My interest in supernovae was nurtured by my girlfriend Silvia (later my wife) whom I met at CERN and the only trained astronomer in my surroundings at that time. At our wedding, Héctor gave a memorable speech, where he expressed the injustice that all other speeches were delivered by my relatives and were mostly about me! He rightfully brought Silvia into the focus of the party. That was so typical of Héctor!

In many respects Héctor lived by the Groucho Marx principle "I don't care to belong to a club that accepts people like me as members". He would never avoid a conflict, even with his closest friends, if he felt the other person was wrong, especially on scientific matters. One memorable Héctor anecdote was when he one morning found a PhD thesis on theoretical particle physics in the library of the institute. With his characteristic curiosity and speed of mind, he had found serious mistakes within minutes after he opened the manuscript. Although the thesis supervisor was somebody that Héctor considered a friend, Héctor posed a non-negotiable ultimatum: Either the thesis was immediately withdrawn or he would make a scandal at the thesis dissertation. Nobody doubted that Héctor would stand by his words: The thesis was withdrawn. To my knowledge, this is the only time such a thing has happened in Sweden.

During the years, I went to many conferences with Héctor, and I always came back with Héctor stories that would amuse family and colleagues for weeks. One such case was the 1994 neutrino conference in Eilat. Attracted to the field by Héctor, I had joined Buford Price's AMANDA group in UC Berkeley, i.e., in parallel with the supernova work at the Lawrence Berkeley Lab. The South Pole neutrino telescope was the predecessor of IceCube. Thanks to this good move, I could get a four year job in Stockholm in 1994 with the team that Per-Olof Hulth was putting together. The first few months in Sweden were very hectic, the first site data from South Pole had arrived and I did the first analysis of the ice optical properties together with Christian Walck and Lars Bergström. Although the results were not really good news for a rapid development of a neutrino telescope in Antartica, Héctor felt that the Stockholm contribution was worthwhile highlighting in Eilat. He managed to twist the arms of the organizers (his friends, of course) to put me among the plenary speakers of the June meeting, not without offending the scheduled senior AMANDA speaker, a well-known figure in the field. My talk received a lot of attention, and John Learned, the leader of the competing DUMAND experiment outside of Hawaii, fired off a number of questions and remarks that Hector (but not me!) felt were unfair: “a vicious attack". Héctor immediately jumped up in my defence and got into a heated argument with John, with plenty of mutual insults, that stopped just short of a fist fight.

I felt very bad after that episode and was unsure how I would handle the rest of the conference until I noticed that, just a few hours after the fight, John and Héctor were having a very relaxed conversation in the lobby of the conference venue and were 
behaving as they had been eternal best friends! (I witnessed this "spin-flip" behaviour in Héctor several times after that. Once the heat of the discussion had cooled off, he could go back and act as absolutely nothing had happened). By then, he was already upset (again) with somebody else at the conference, which made the return flight from Eilat to Tel Aviv an embarrassing event, since the new target for Héctor's fury was sitting in the row next to ours...

Clearly, being so close to such a colourful personality was somewhat contagious.

Watching him argue about scientific matters taught me a lot about finding the essence of any new idea. He was a master of detecting the weakness in both new concepts and people, and would fire devastating comments that would take the conversation in a direction of his choice. One of the most flattering comments I have received from a colleague and friend of Héctor was "you are a lot like Héctor - just a lot more tolerable”.

Under all circumstances, being a young scientist (and later not so young!) around Héctor was a fantastic treat. He always introduced me and other young people around him to his "big shot" friends, and opened doors that were otherwise locked for us. As a person, he was extremely helpful, a friend to trust, especially in difficult moments.

I cannot thank him enough for all the support he gave to me throughout my scientific career, but also for the great advice I got in many other areas in life. The harsh criticism I received at times were certainly very motivating. Pleasing Héctor was nearly impossible, but we all tried hard, because he was worth it! 